\title{
Erythropoietin Attenuation Of Early Upregulation Of Kidney Injury Parameters Levels In Cisplatin-Treated Rats
}

\author{
Author: Ayad Ali Hussein \\ University of Kufa/ Faculty of Pharmacy/ Department of Pharmacology and \\ Toxicology.
}

\section{$\underline{\text { Abstract }}$}

Background: cisplatin chemotherapy can cause acute kidney injury (AKI) in about $30 \%$ of patients that act as a major dose-limiting problem complicating chemotherapy by cisplatin that still commonly indicated as first line treatment of cancer management without relatively less toxic and equally effective substitutes. Cisplatin induced-DNA damage and oxidativeinflammatory hyper-reactivity with apoptosis are the bases for cisplatin-induced AKI. Erythropoietin has approved antioxidant, anti-inflammatory and to some extent antiapoptotic effects that may have ameliorative effect on early cisplatin-induced AKI. Kidney injury molecules-1 (KIM-1) and interleukin-18 (IL-18) were assumed to be more sensitive for detecting AKI than the traditional kidney function tests (serum creatinine and urea).

Objective: assess the effect of erythropoietin on early upregulation of kidney injury parameters after cisplatin treatment.

Methods: 27 adult male rats were randomized into three groups containing nine rats for each as follow: Sham group: rats received daily intraperitoneal injection of placebo for 4 days. Cisplatin group: rats received single intraperitoneal injection of $6 \mathrm{mg} / \mathrm{kg}$ cisplatin. Cisplatin+Erythropoietin group: rats received single intraperitoneal injection of $6 \mathrm{mg} / \mathrm{kg}$ cisplatin and daily intraperitoneal injection of $100 \mathrm{IU} / \mathrm{kg}$ erythropoietin for 4 days. After scarification, blood samples are collected for serum creatinine measurement, kidneys are processed for measurement of renal MDA, KIM-1 and IL-18 and histopathlogical evaluation.

Results: cisplatin produced significant $(\mathrm{P}<0.05)$ change in serum creatinine level, kidney MDA, KIM-1, IL-18 and score of histopathological damage severity when compared to that of other groups. In Cisplatin + Erythropoietin group, Serum creatinine, and kidney MDA, KIM-1, IL-18 and total severity score were significantly $(\mathrm{P}<0.05)$ less than that in cisplatin group.

Conclusion: erythropoietin ameliorated early cisplatin-induced AKI evidenced by improving early injury parameters that give rise for early involvement of erythropoietin as early preventive measure for protection from nephrotoxicity.

Keywords: cisplatin, acute kidney injury, erythropoietin, KIM-1, IL-18

\section{Introduction}

Cisplatin (cis-diamminedichloroplatinum (II)) is an antitumor agent that commonly used in the management of various solidorgan tumors. Toxicities due to cisplatin can occur as nephrotoxicity, myelosuppressiorn, gastrotoxicity, neototoxicity, and allergic reactions $(1,2)$. Nephrotoxicity act as a major dose-limiting problem complicating chemotherapy by cisplatin that still commonly indicated as first line treatment of cancer management without relatively less toxic and equally effective substitutes. Cisplatin chemotherapy can cause nephrotoxicity as AKI in about $30 \%$ of patient despite use of 
ISSN (Print):1992-92 18, ISSN (Online):1992-92 18

\section{DOI: https://doi.org/10.32792/utq/utjmed/18/2/1/01}

powerful hydration as a protective measure (3-5).

Cisplatin induced-DNA damage and oxidative- inflammatory hyper-reactivity with apoptosis are the bases for cisplatininduced AKI through a complex mechanism (6). Inflammation associated with apoptosis are suggested by many studies to act as crucial pathophysiological mechanism in cisplatin-induced AKI (7-9). The proinflammatory cytokine, tumor necrosis factor (TNF)-alpha mediate reactive oxygen species overproduction, apoptosis $(10,11)$ and stimulation of the overproduction of cytokines and/or chemokines that leads to again further inflammation $(8,9)$. Thus, interfering with the inflammation, oxidation and /or apoptosis processes due to cisplatin administration may be protective from cisplatin-induced AKI.

Kidney injury molecule-1 (KIM-1) is a $36 \mathrm{kDa}$ (unglycosolated) type I glycoprotein found on the cell membrane that contains a six-cysteine immunoglobulin-like domain and a mucin domain in its extracellular portion (12). KIM-1 is found to be undetectably expressed in the normal rat kidney but significantly upregulated post-ischemia (12). After proximal tubular injury of varying etiology in vitro, KIM-1 ectodomain was expressed out from cells (13) while in vivo, expressed into the urine in rodents and humans (14-17). In many experimental and clinical studies, KIM-1 was considered as an earlier indicator of AKI than the traditional tubular enzymes and biomarkers $(18,19)$. Acute tubular necrosis (ATN) caused about 12-fold increase in KIM1 level that normalized by gender, age and delay period between insult and sampling adjustment (18). KIM-1 suggested and considered be a stable, specific and sensitive AKI biological marker in adult clinical studies (20).

Interleukin-18 (IL-18) is previously recognized as interferon- $\gamma$-inducing factor. Biologically active form of IL18 is produced after activation by caspase-1 of a $24 \mathrm{kDa}$ inactive precursor (21-23). IL-18 have various immunomodulatory properties and found to play a essential role in host defense mechanism against various infections (23). IL-18 levels upregulated significantly in patients with AKI after ischemic ATN and transplantation (24). Urinary IL-18 was found to be an early marker of AKI in adult patients with acute respiratory distress syndrome, that upregulated before increasing in serum creatinine by $1-2$ days, and was an independent predictor of death (25). In mice, cisplatin induced AKI and increased levels of kidney IL-18 (26).

Erythropoietin is a protein with a erythropoietic effect that synthetized in response to hypoxia by peritubular cells in the kidneys and to some extent in the liver (27). Tissue oxygen levels deficiency leads to stimulation of the activity of hypoxia-inducible factor $2 \mathrm{a}$, which stimulate process of transcription by binding to hypoxiaresponsive elements of the erythropoietin gene $(28,29)$.

In the bone marrow, in addition to proliferating factors as stem cell factor, insulin like growth factor 1 and granulocyte macrophage colonystimulating factor, erythropoietin protects erythroid progenitor cells from apoptosis, and activate specialization of erythroid progenitors from the 
ISSN (Print):1992-92 18, ISSN (Online):1992-92 18

\section{DOI: https://doi.org/10.32792/utq/utjmed/18/2/1/01}

normoblast stage to ultimately erythrocytes in mature stage (30).

Outside of the erythropoietic system, erythropoietin has been revealed to have an important role in tissues. Erythropoietin receptors are found to be expressed widely and a biological response to erythropoietin have been observed in many cell types like cardiac, neural, and endothelial cells $(31,32)$.

Recombinant human erythropoietin (rHuEPO) is used to treat anemia and has been shown to act as a cytoprotectant in different models of AKI, including ischemic and toxic AKI $(33,34)$.

Erythropoietin can produce nitric oxide by stimulation of endothelial cells, which characterized by anti-apoptotic effects $(35,36)$. The study Work on the confirmation role for rHuEPO in localized cisplatin-induced renal injury and proposed that an anti-apoptosis effect produced by the interaction of erythropoietin with its receptor (EPOR) is an important mechanism for renal preservation (37).

Numerous studies have reported the involvement of erythropoietin in the promotion of cell survival signaling cascades such as the JAK/STAT, PKC, and PI3K/Akt signaling pathways, and in the upregulation of anti-apoptotic protein expression in a spectrum of experimental models (37-39). Erythropoietin activates cell survival pathways by inducing the phosphorylation of JAK2/STAT to attenuate ER stress (40).

\section{Methods}

A total of 27 adult male of Swiss Albino rats (weighing 90-110g) were supplied by Animal Resource Center, University of Kufa. Animals were accommodated in the animal house of Faculty of Pharmacy/ Kufa University in a room with $24 \pm 2{ }^{\circ} \mathrm{C}$ temperature. Rats were under 12-hours light exposure and 12- hours without light exposure throughout the experiment and animals were able to reach water and diet freely. The Animal Care and Research Committee of Kufa University approved the experiments and the study followed the guide of National Research Council for the handling of Laboratory Animals. One week after adaptation, the rats were classified into three groups containing nine rats for each as follow:

- Sham group: rats received daily intraperitoneal injection of placebo for 4 days and underwent the same anesthetic and surgical procedures of other groups of the present study.

- Cisplatin group: rats received single intraperitoneal injection of $6 \mathrm{mg} / \mathrm{kg}$ cisplatin for nephrotoxicity induction in rats according to previous studies. It was manufactured by cipla, (India) as 50 $\mathrm{mg} / 50 \mathrm{~mL}$ (Cytoplatin-50 aqueous vial of $50 \mathrm{ml})$.

- Cisplatin+Erythropoietin group: rats received single intraperitoneal injection of $6 \mathrm{mg} / \mathrm{kg}$ cisplatin and daily intraperitoneal injection of $100 \mathrm{IU} / \mathrm{kg}$ erythropoietin for 4 days. It was manufactured by CinnaGen co, (Iran) as 4000IU in syringe.

Measurement of the early kidney injury parameters

At the end o0f experiment, all the animals were sacrificed on 4th day of cisplatin administration and right kidney is taken and homogenized with $0.1 \mathrm{M}$ potassium phosphate buffer (pH7.4) in a ratio of mixing of $1: 10$ (w/v) and the homogenization done by a high intensity ultrasonic liquid processor. kidney homogenate was 
Web Site: https://jmed.utq.edu.iq

Email:utjmed@utq.edu.iq

ISSN (Print):1992-92 18, ISSN (Online):1992-92 18

DOI: https://doi.org/10.32792/utq/utjmed/18/2/1/01

used for determination of renal KIM-

1(using Sigma MaxiSorp; Nunc- EZ-

Biotin Quantitation Kit, USA) and IL-

18 (using MBL ELISA kit, Japan).

Measurement of kidney function parameter

Immediately after scarification, directly from the heart, blood about $(1.5 \mathrm{ml})$ was withdrawn. The samples were left for clotting at $37^{\circ} \mathrm{C}$ then centrifugation at $10000 \mathrm{rpm}$ for 30 min; then the serum from each sample was separated from samples and examined for evaluation of serum creatinine using SPINREACT kit, Spain.

Measurement of oxidative stress parameter

Malondialdehyde (MDA), the lipid peroxidation final yield, was determined in kidney homogenate of sacrificed animals according to the method described by Buege and Aust (1978) which demonstrated that the reaction of MDA with thiobarbituric acid (TBA) produce a red chromophore (colored) MDA-TBA complex, , which can be estimated for quantification of MDA by spectrophotometry (41).

Histopathological Evaluation

The left kidney was fixed in $10 \%$ formalin. Light microscope with magnification power of $(\times 400)$ was used for examining the slide sections of renal tissues for the histological changes assessment at corticomedullary junction. Degree severity of damages in kidney parenchyma was evaluated and scored by pathologist who was uninformed of the treatment in the study by a semi-quantitative scale designed by McWhinnie et al
(1986) for severity of renal damage evaluation (42) by dividing slide section zone into 10 small zones (intersections). 0 to 3 score was assumed for each intersection according to its tubular profile as follow:

$0=$ normal (no damage seen) parenchyma.

$1=$ when not more than $1 / 3$ of tubular profile is damaged. (vacuolation, interstitial edema, atrophy of tubule, severe tubular necrosis, and interstitial inflammation)

$2=$ when greater than $1 / 3$ and less than $2 / 3$ of the tubular profile is damaged.

$3=$ when greater than $2 / 3$ of the tubular profile is damaged.

The summation of the all ten intersections scores (with a maximum score of 30) for each kidney (slide section) was referred as total severity score, according to which the severity of kidney injury was categorized as follow: when total severity score is zero the slide was considered normal, when the score is (1-10) the kidney injury considered mild, when (11-20) considered moderate and when (21-30) considered severe kidney injury.

\section{Statistical Analysis}

SPSS 16.0 for windows Inc. was utilized for statistical analysis of data of all the study results. Normally distributed data of quantitative variables were expressed as mean \pm SEM. Multiple comparisons among all study groups were accomplished by Analysis of Variance (ANOVA) then LSD methods used for post-hoc tests. The total severity score statistical significance were examined by the 
Web Site: https://jmed.utq.edu.iq

Email:utjmed@utq.edu.iq

ISSN (Print):1992-92 18, ISSN (Online):1992-92 18

DOI: https://doi.org/10.32792/utq/utjmed/18/2/1/01

Mann-Whitney U test (non-normally level of statistical significance was distributed variable). In all analyses, $0.05(\mathrm{P}<0.05)$.

\section{$\underline{\text { Results }}$}

Effects on kidney injury parameters (KIM-1 and IL-18)

Cisplatin administration $(6 \mathrm{mg} / \mathrm{kg}$ ) lead to significant increment $(\mathrm{p}<0.05)$ in KIM-1 and IL-18 levels when compared with sham group levels of same parameters as shown in figure (1). In Cisplatin + erythropoitein (100 IU/kg) treated group, KIM-1 and IL-18 were characterized by significant $(p<0.05)$ elevation in their level based on sham group level comparisons and significant $(\mathrm{p}<0.05)$ lowering based on cisplatin group level comparisons as shown in figure (1) below.

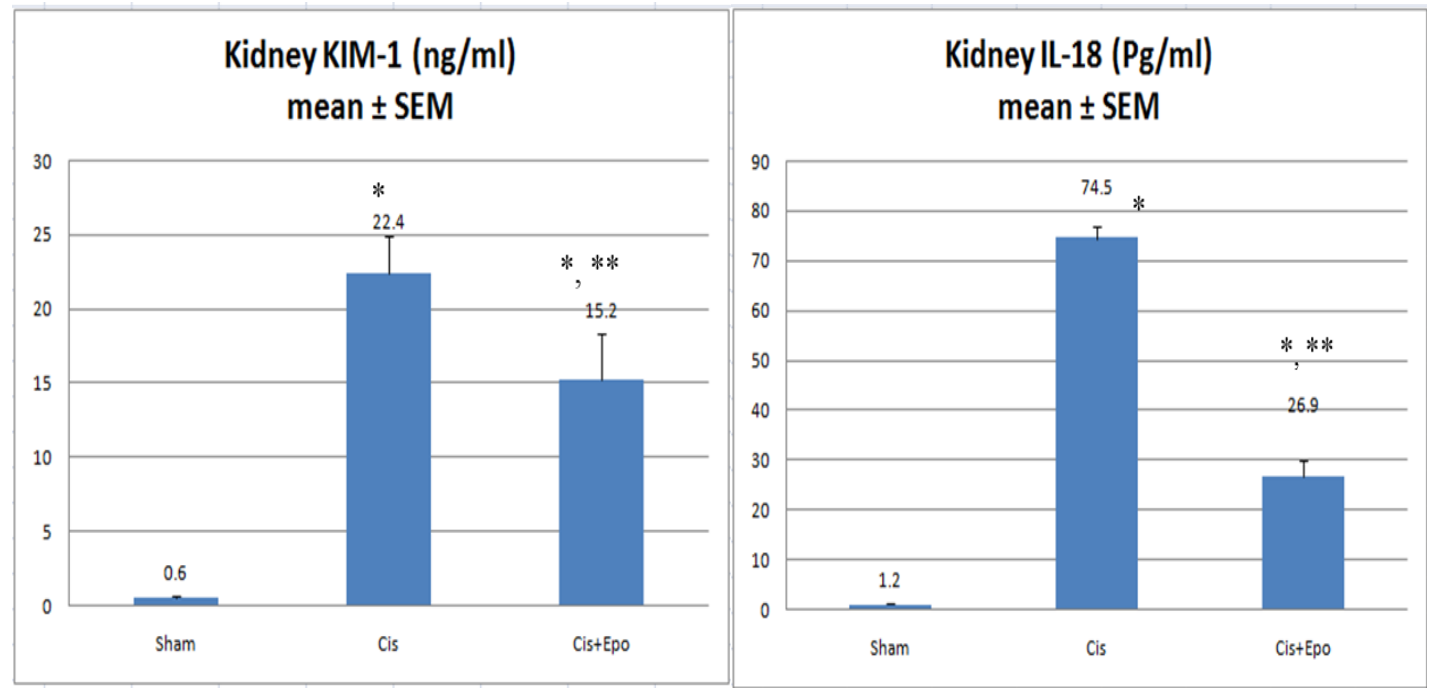

Figure (1): chart shows mean \pm SEM differences in KIM-1 (pg/ml) and IL-18 (ng/ml) levels of the three study groups after the end of experiment. ( $\mathrm{N}=9$ for each, * Significant change in comparison to sham group, ${ }^{*}$ Significant change in comparison to cisplatin group).

\section{Effects on kidney function parameters}

Cisplatin administration $(6 \mathrm{mg} / \mathrm{kg})$ lead to significant increment $(\mathrm{p}<0.05)$ in serum creatinin level when compared with sham group level as shown in figure (2). In Cisplatin + erythropoitein $(100 \mathrm{IU} / \mathrm{kg})$ treated group, serum creatinin was characterized by significant $(p<0.05)$ elevation in its level based on sham group level comparisons and significant $(\mathrm{p}<0.05)$ lowering based on cisplatin group level comparisons as shown in figure (2) below. 
Web Site: https://jmed.utq.edu.iq

Email:utjmed@utq.edu.iq

ISSN (Print):1992-92 18, ISSN (Online):1992-92 18

DOI: https://doi.org/10.32792/utq/utjmed/18/2/1/01

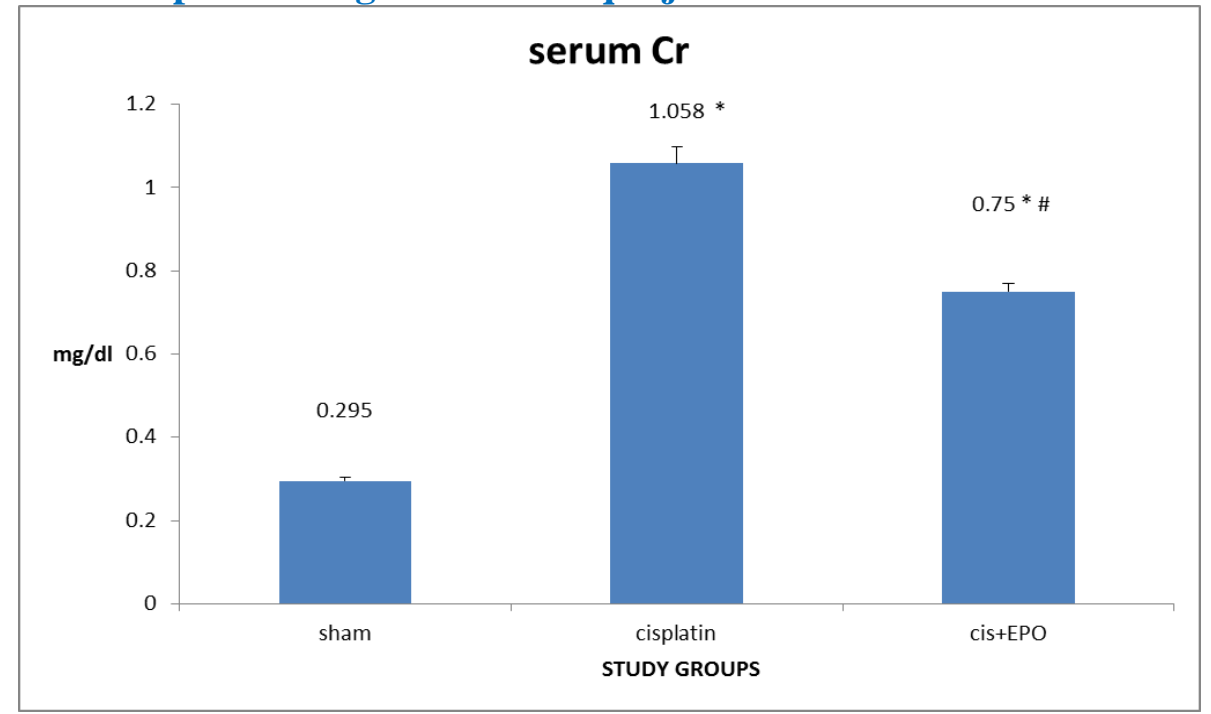

Figure (2): chart shows mean \pm SEM differences in serum creatinin levels $(\mathrm{mg} / \mathrm{dl})$ of the three study groups after the end of experiment. ( $N=9$ for each, * Significant in comparison to sham group, *\# Significant in comparison to cisplatin group).

\section{Effects on renal oxidative stress (Kidney MDA)}

Cisplatin administration $(6 \mathrm{mg} / \mathrm{kg})$ lead to significant increment $(\mathrm{p}<0.05)$ in kidney MDA level when compared with sham group level as shown in figure (3). In Cisplatin + erythropoitein (100 IU/kg) treated group, kidney MDA was characterized by significant $(\mathrm{p}<0.05)$ elevation in its level based on sham group level comparisons and significant $(\mathrm{p}<0.05)$ lowering based on cisplatin group level comparisons as shown in figure (3) below.

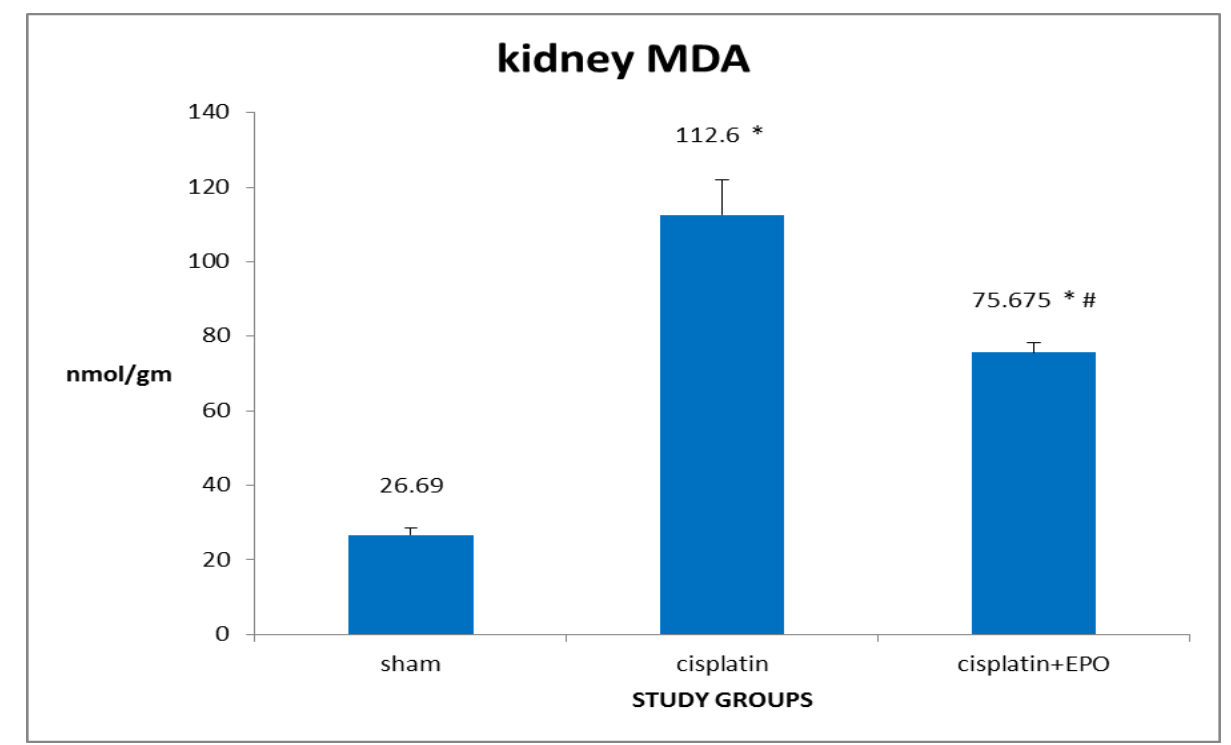


Web Site: https://jmed.utq.edu.iq

Email:utjmed@utq.edu.iq

ISSN (Print):1992-92 18, ISSN (Online):1992-92 18

DOI: https://doi.org/10.32792/utq/utjmed/18/2/1/01

Figure (3): chart shows mean \pm SEM differences in kidney MDA levels (nmol/gm) of the three study groups after the end of experiment. ( $N=9$ for each, * Significant in comparison to sham group, *\# Significant in comparison to cisplatin group).

\section{Effects on Kidney Parenchyma}

Cisplatin treatment lead to severe kidney injury for 6 rats $(66.6 \%)$ in cisplatin group and 3 rats $(33.4 \%)$ show moderate severity. These damages are significant when compared with that of sham group where slide sections of kidneys of 7 rats $(77.7 \%)$ in this group showed normal parenchyma while 2 rats $(22.2 \%)$ showed mild damages. In cisplatin group, slide sections of kidneys of showed severe grading while in cisplatin + erythropoietin group, 2 rats $(22.2 \%)$ in this group showed severe damages, 3 rats $(55.5 \%)$ showed moderate damages and 2 rats $(22.2 \%)$ showed mild damages.

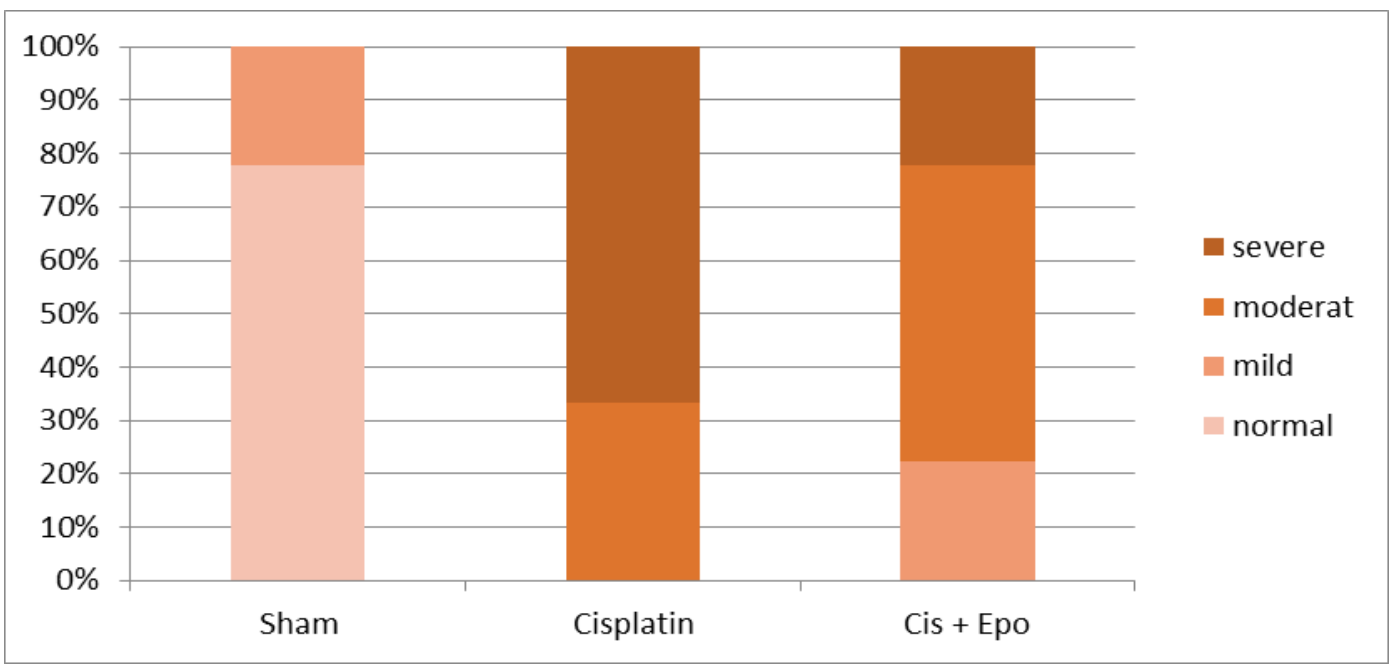

Figure (4): chart shows relative frequency of histopathological damages severity of the three study groups at the end of experiment ( $\mathrm{N}=9$ in each).

The below photomicrographs demonstrate the predominant histopathological findings in each group.

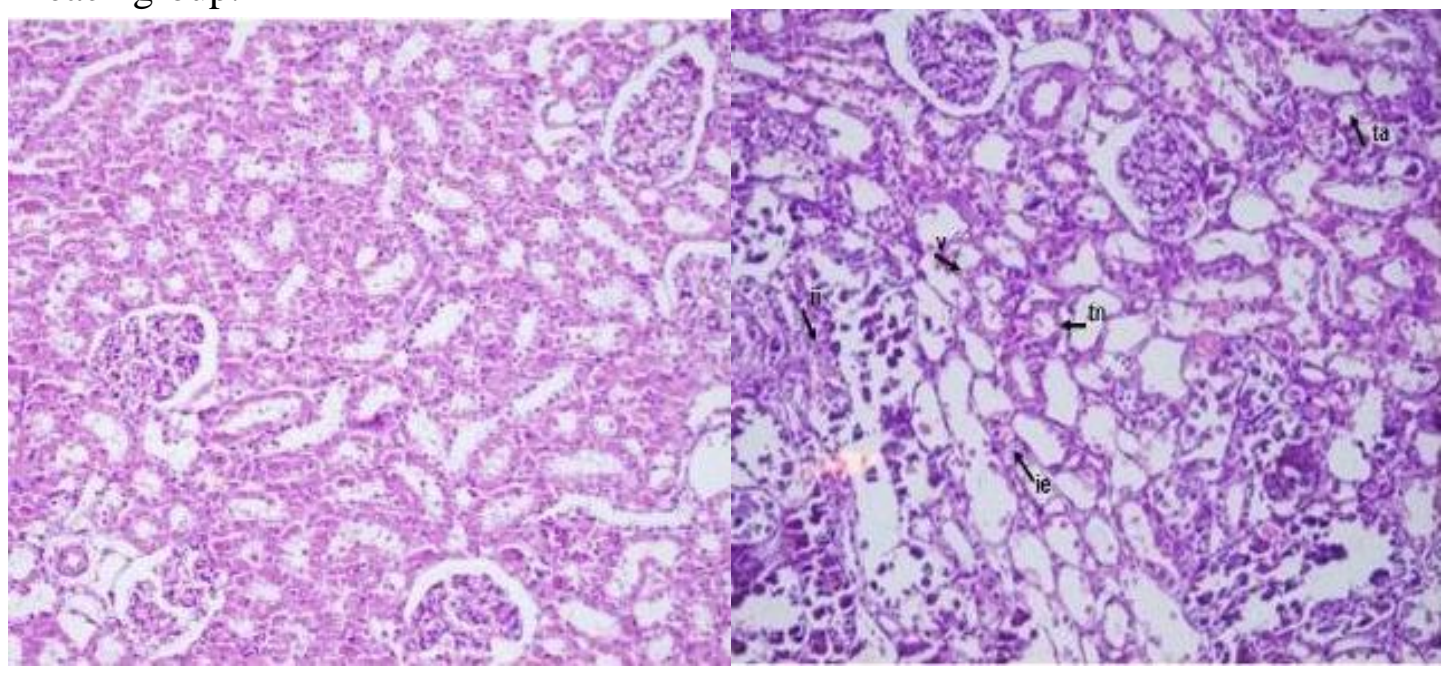


Web Site: https://jmed.utq.edu.iq

Email:utjmed@utq.edu.iq

ISSN (Print):1992-92 18, ISSN (Online):1992-92 18

DOI: https://doi.org/10.32792/utq/utjmed/18/2/1/01

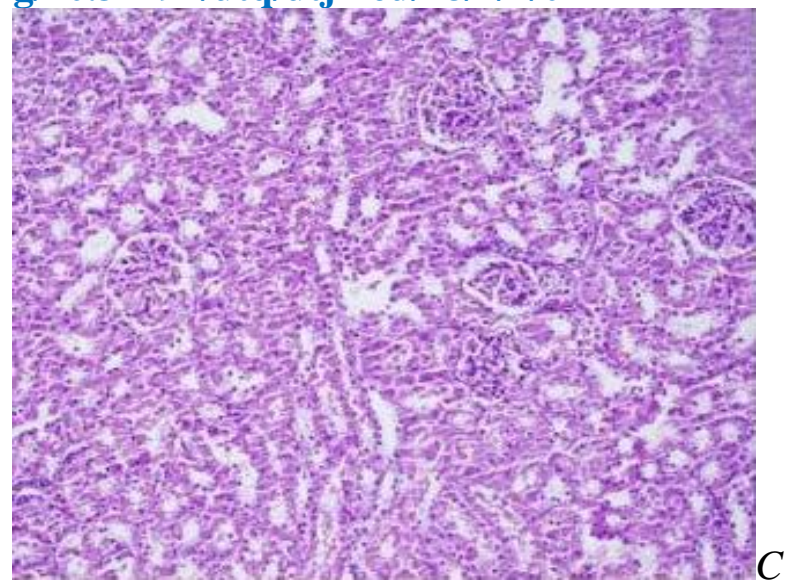

Figure (5): Photomicrographs of kidney intersection stained with haematoxylin and Eosin (X 400). A, sham; B, cisplatin treatment alone [left to right (ii) interstitial inflammation, (v) vasculation, (i.e.) interstitial edema, (tn) tubular necrosis, (ta) tubular atrophy]; C, cisplatin + erythropoietin.

Table (1): The injury severity differences among the three study groups at the end of experiment.

\begin{tabular}{|c|c|c|c|c|c|c|}
\hline $\begin{array}{c}\text { Histopathological } \\
\text { injury severity }\end{array}$ & \multicolumn{9}{c|}{ Study groups } \\
\cline { 2 - 8 } & \multicolumn{2}{|c|}{ Sham } & \multicolumn{2}{c|}{ Cisplatin } & \multicolumn{2}{c|}{ Cis + Epo } \\
\hline Normal & 7 & $\%$ & N & $\%$ & N & $\%$ \\
\hline Mild & 2 & 22.2 & 0 & 0 & 2 & 22.2 \\
\hline Moderate & 0 & 0 & 3 & 33.4 & 5 & 55.6 \\
\hline Severe & 0 & 0 & 6 & 66.6 & 2 & 22.2 \\
\hline Total & 9 & 100 & 9 & 100 & 9 & 100 \\
\hline Grade of the group & \multicolumn{2}{|c|}{ Normal } & Severe & Moderate \\
\hline
\end{tabular}

As shown in figure (6) below, Cisplatin administration significantly $(p<0.05)$ increased total severity score than that of sham group. Adding erythropoietin to rats in addition to cisplatin therapy led to significant $(\mathrm{p}<0.05)$ decrease in total severity score than that in cisplatin treated rats. 
Web Site: https://jmed.utq.edu.iq

Email:utjmed@utq.edu.iq

ISSN (Print):1992-92 18, ISSN (Online):1992-92 18

DOI: https://doi.org/10.32792/utq/utjmed/18/2/1/01

Figure (6): chart shows mean \pm SEM differences in total severity score of the

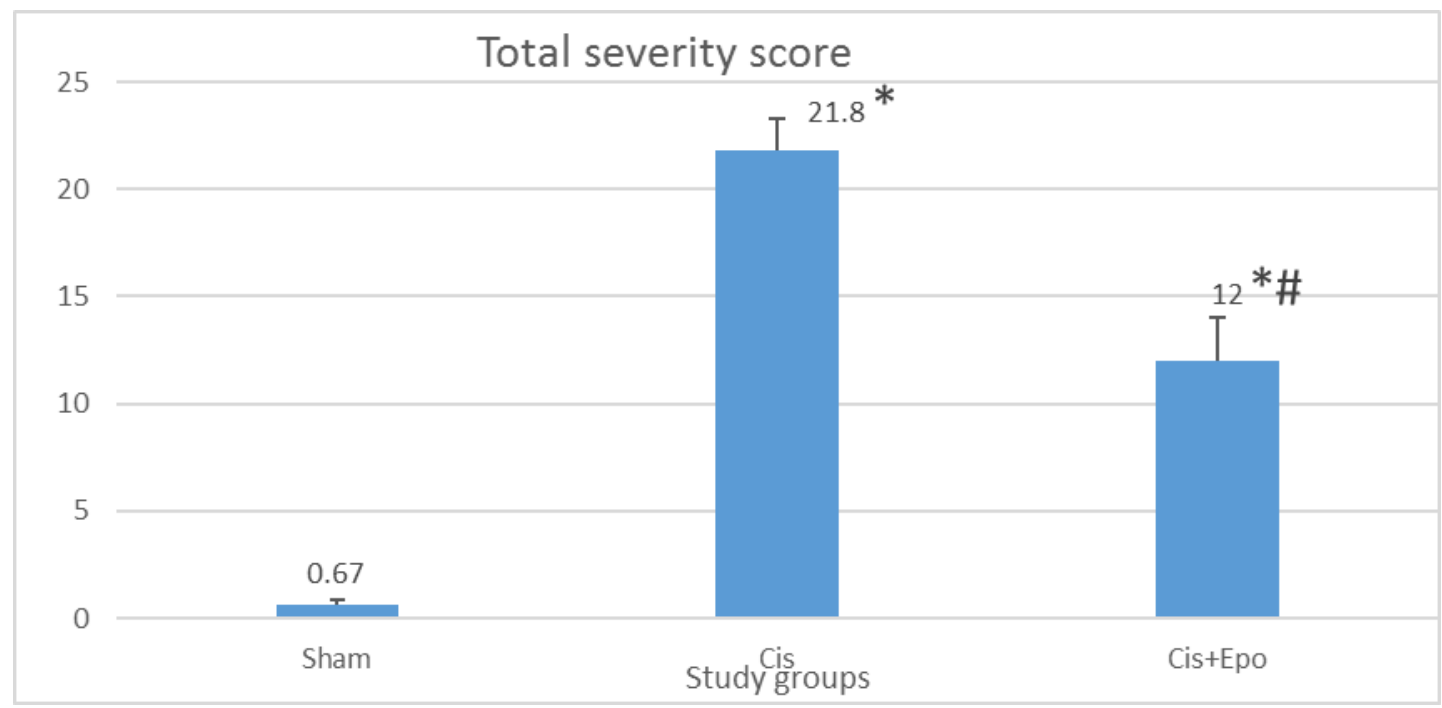

three study groups after the end of experiment. ( $N=9$ for each, * Significant in comparison to sham group, *\# Significant in comparison to cisplatin group).

\section{Discussion}

Effects of cisplatin on kidney injury parameters (KIM-1 and IL-18)

In the present study, rats of sham group revealed low to undetectable levels of KIM-1. Cisplatin caused dramatical upregulation in levels of KIM-1 in the kidney of rats of Cisplatin group. In several studies, KIM-1 appeared in the urine of experimental rodents and humans after cisplatin-induced injury of proximal tubular (14-17). Furthermore, Kim-1 was considered more sensitive than the conventional BUN, serum creatinine, urinary NAG, glycosuria, or proteinuria for detecting AKI than after cisplatin administration and renal ischemia/reperfusion $(\mathrm{I} / \mathrm{R})$ in rat models (19).

IL-18 was significantly elevated in Cisplatin group compared with the normal values in Sham group of the present study. In a study, 0-4 days after operation of transplantation, acute decline in serum creatinine concentrations was predicted by a rapid decline in urinary IL-18 levels (24). An explanation of this was that these inflammatory reactions resulted from TNF-alpha which stimulate the cytokines and/or chemokines generation of such as monocyte chemoattractant protein-1 (MCP-1) and ICAM-1 $(8,9)$. IL-18 expression was revealed by immunohistochemical staining of biopsies of the distal tubular epithelium of renal transplant. In the proximal tubules of patients with acute rejection, strong positive immunoreactivity was demonstrated with strong immunoreactivity of infiltrating leukocytes, and endothelium, that assumed robust upregulation of chemoattractant IL-18 due to immunopathological reactions (43).

Effect of Cisplatin on Kidney Function 
ISSN (Print):1992-92 18, ISSN (Online):1992-92 18

\section{DOI: https://doi.org/10.32792/utq/utjmed/18/2/1/01}

This study shows that serum creatinine were elevated significantly $(\mathrm{p}<0.05)$ after cisplatin administration in comparison to that of sham group. In many studies, cisplatin nephrotoxic effect was resulted after 10 days of cisplatin treatment and is demonstrated as low GFR and high serum creatinine $(4,6,44)$. Several studies have revealed that administration a single dose of cisplatin $(7.5 \mathrm{mg} / \mathrm{kg} \mathrm{BW})$ can induce renal injury in rat model with prominent elevation in levels of serum creatinine and BUN in cisplatin group compared to that in the group of untreated animals. It is approved that increased creatinine is associated with renal dysfunction or due to nephrotoxic agents (45). Another study showed that $5 \mathrm{mg} / \mathrm{kg}$ body weight intraperitoneal injection of cisplatin resulted in significant elevation in the BUN, serum creatinine, urine volume and kidney weight/ the total body weight percentage when compared to that of the cisplatin-untreated rats (46).

\section{Effects of Cisplatin on Kidney} Oxidative Stress Parameter (MDA)

In the current study, kidney MDA levels were significantly $(\mathrm{P}<0.05)$ upregulated in cisplatin group as compared to that of sham group, this result assumed that significant activation in oxidation process leads to higher lipid peroxidation. Our results are in good agreement with that of other studies. Palipoch et al. (2013) showed that MDA level in renal tissues was significantly elevated in animal of cisplatin group as compared with cisplatin-untreated animal in sham group (47). Oxidative stress contributes to cisplatin-induced AKI by severe activation of reactive oxygen species generation and inhibiting of enzymatic antioxidants activities such as superoxide dismutase and catalase $(48,49)$. Cisplatin stimulate reactive oxygen species generation by stimulation of expression of gene of NADPH oxidase causing further stimulation of lipid peroxidation (manifested by increasing the level of end product of lipid peroxidation, the MDA), finally this led to membrane damage and nephrotoxicity $(48,49)$.

Effects of Cisplatin on Kidney
Parenchyma

The present study found that the prevalence of kidney injury caused by cisplatin administration was highly severe. The ratio is $77.7 \%$ (7 rats), which confirm the effect of cisplatin which induce kidney injury in renal tubules. A study suggested that cisplatin induced sub lethal AKI, with alterations to renal function and histology (50). The mechanisms of cisplatin-induced renal injury are related to several factors, including higher oxidation process, inflammatory process, mitochondrial dysfunction, DNA damage, and apoptosis $(6,51)$.

The cisplatin uptake by tubular cells led to activation of oxidation and inhibiting antioxidant system that resulted in apoptosis initiation through complex signaling pathways that led to tubular cell injury and ultimately death. Vigorous inflammatory response which activated due to oxidative stress led to additional exacerbation of renal tissue damage $(6,44)$. Cisplatin may initiate ischemic injury of the kidneys by direct injury of renal vasculature and then result in diminished renal blood flow (44). All the stated effects, together, resulted 
Web Site: https://jmed.utq.edu.iq

Email:utjmed@utq.edu.iq

ISSN (Print):1992-92 18, ISSN (Online):1992-92 18

\section{DOI: https://doi.org/10.32792/utq/utjmed/18/2/1/01}

finally in the histological damages to kidney (44).

Effects of Erythropoietin on kidney injury parameters

A significant decrement in KIM-1 and IL-18 levels of rats treated with erythropoietin and cisplatin as comparing with that in cisplatin group noticed in the present study. This believed to be due to the protective effect of erythropoietin in renal tubules. A similar study revealed that erythropoietin can prevent and recover renal injury in rat model administered cisplatin $(6 \mathrm{mg} / \mathrm{kg})$ and daily erythropoietin $(100 \mathrm{U} / \mathrm{kg})$ for 9 day (52).

In rats, erythropoietin enhanced recovery from cisplatin-induced AKI (52), suggesting that it acts directly on impaired tubular cells and stimulates their regeneration. Studies on renal epithelial cells of tubules demonstrated that caspase and mitochondria play critical role in apoptosis due to cisplatin (53). Mitochondria and the endoplasmic reticulum (ER) are involved in the intrinsic pathway of apoptosis (54). In addition, the endoplasmic reticulum stimulated apoptosis by making mitochondria more sensitive to many extrinsic and intrinsic stimuli and then inducing apoptotic cell death (55).

Effect of Erythropoietin on kidney Function

In this study, we notice a significant decrement in serum urea and serum creatinine levels of rats treated with erythropoietin and cisplstin as comparing with cisplatin group. This believed to be due to the renoprotective effect of erythropoietin in renal tubules. Several studies have noticed that erythropoietin can inhibit renal damages in rat model administered cisplatin $(6 \mathrm{mg} / \mathrm{kg})$ and daily erythropoietin $(100 \mathrm{U} / \mathrm{kg})$ for 9 days (52). In another study, significant serum creatinine and BUN concentrations were lowering in rats received erythropoietin after cisplatin injection than in the cisplatin-injected rats $(50)$.

Effect of Erythropoietin on Kidney Oxidative Stress Parameter (MDA)

The animals that received erythropoietin had significant $(\mathrm{P}<0.05)$ lower level of kidney MDA than that resulted in cisplatin group of the current study. Erythropoietin has approved antioxidant effects $(56,57)$. Effect of erythropoietin in reduction of apoptosis and oxidative stress (58) may play major ameliorating effects on cisplatin-induced AKI. Erythropoietin stimulate tissue activity of superoxide dismutase, catalase, and glutathione peroxidase (58). Ates et al (59) reported that increased the level of glutathione $(\mathrm{GSH})$ resulted from erythropoietin treatment after ischemia- reperfusion injury induction in rats. Sakanaka et al (60) have also demonstrated that erythropoietin stimulated the activity of antioxidant enzymes, such as superoxide dismutase, catalase, and glutathione peroxidase in neurons. Activation of antioxidant enzymatic $(58,60)$ and nonenzymatic (59) systems lead to inhibition in lipid peroxidation due to cisplatin exposure and thereby less production of MDA (end product of lipid peroxidation) $(48,49)$.

Effect of Erythropoietin on Kidney Parenchyma 
ISSN (Print):1992-92 18, ISSN (Online):1992-92 18

\section{DOI: https://doi.org/10.32792/utq/utjmed/18/2/1/01}

In the present study, cisplatin + erythropoietin administration caused significant decrement in kidney injury severity in comparison to that of cisplatin treated group. Although no rats in cisplatin + erythropoietin group showed normal kidney parenchyma (same finding of cisplatin group), two rats only $(22.2 \%)$ have showed severe kidney injury which is good improvement when compared with 6 rats $(66.6 \%)$ of all cisplatin group rats that revealed severe kidney injury. In another study, almost same result was showed. No glomerular or vascular lesions were observed, treatment with erythropoietin modified the effects of cisplatin on renal histology, as no or very little necrosis or tubular cast material was detected in the control and erythropoietin treated groups (50). In animals treated with erythropoietin, significant improvement in tubular regeneration, tubular cell proliferation and thereby recovery of the renal function was approved and assumed that this effect may be through growth factor-like effect of erythropoietin in tubular cell (52). In vitro, erythropoietin stimulate (in a dosedependent manner) proliferation and chemotaxis of endothelial progenitor cells which in turn activates vascular reparative mechanisms and neoangiogenesis (61).

Conclusion: Cisplatin caused nephrotoxicity in rat evidenced by upregulation of kidney injury parameters, deterioration in kidney function, histopathological changes while erythropoietin administration with cisplatin ameliorated early cisplatin-induced acute kidney injury evidenced by improving early injury parameters that give rise for early involvement of erythropoietin as early preventive measure for protection from nephrotoxicity.

Competing interest: none.

\section{$\underline{\text { References }}$}

1- Hartmann JT, Fels LM, Knop S, Stolt H, Kanz L, Bokemeyer C. A randomized trial comparing the nephrotoxicity of cisplatin/ifosfamide-based combination chemotherapy with or without amifostine in patients with solid tumors. Invest. New Drugs 2000, 18, 281-289.

2- Hartmann JT, Lipp HP. Toxicity of platinum compounds. Expert Opin. Pharmacother. 2003, 4, 889-901.

3- Sastry J, Kellie SJ. Severe neurotoxicity, ototoxicity and nephrotoxicity following high-dose cisplatin and amifostine. Pediatr. Hematol. Oncol. 2005, 22, 441-445

4- Arany I, Safirstein RL. Cisplatin nephrotoxicity. SeminNephrol 2003,23, $460-4$

5- Boulikas, T. Poly(ADP-ribose) synthesis in blocked and damaged cells and its relation to carcinogens. Anticancer Res. 1992, 12, 885-898

6- Yao X, Panichpisal K, Kurtzman N, Nugent K. Cisplatin nephrotoxicity: a review. Am J Med Sci. 2007;334(2):115-124 
ISSN (Print):1992-92 18, ISSN (Online):1992-92 18

\section{DOI: https://doi.org/10.32792/utq/utjmed/18/2/1/01}

7- Deng,J.,Kohda,Y.,Chiao,H.,Wang,Y.,Hu,X.,Hewitt,S.M.,Miyaji,T.,McLer oy,P.,Nibhanupudy, B., Li, S., and Star, R. A.: Interleukin-10 inhibits ischemic and cisplatin-induced acute renal injury, Kidney Int. 2001, 60, 21182128.

8- Ramesh G, and Reeves WB. TNF-alpha mediates chemokine and cytokine expression and renal injury in cisplatin nephrotoxicity, J. Clin. Invest., 2002, 110, 835-842.

9- Dong Z, and Atherton S.Tumor necrosis factor-alpha in cisplatin nephrotoxicity: a homebred foe? Kidney Int., 72, 5e7 (2007).Dong and Atherton 2007

10- Li, M, Balamuthusamy, S. Khan, A M. Maderdrut JL. Simon, EE. and Batuman, V.: Pituitary adenylate cyclase-activating polypeptide prevents cisplatin-induced renal failure, J. Mol. Neurosci., 43, 58e66 (2011).Li et al.,2011

11- Ramesh, G and Reeves, WB.: Salicylate reduces cisplatin nephrotoxicity by inhibition of tumor necrosis factor-alpha, Kidney Int., 65, 490e499 (2004).Ramesh and Reeves 2004

12- Ichimura T, Bonventre JV, Bailly V, Wei H, Hession CA, Cate RL, Sanicola M. Kidney injury molecule-1 (KIM-1), a putative epithelial cell adhesion molecule containing a novel immunoglobulin domain, is upregulated in renal cells after injury. J Biol Chem. 1998;273:4135-42.

13- Bailly V, Zhang Z, Meier W, Cate R, Sanicola M, Bonventre JV. Shedding of kidney injury molecule-1, a putative adhesion protein involved in renal regeneration. J Biol Chem. 2002;277:39739-48.

14- Ichimura T, Hung CC, Yang SA, Stevens JL, Bonventre JV. Kidney injury molecule-1: a tissue and urinary biomarker for nephrotoxicant-induced renal injury. Am J Physiol Renal Physiol. 2004;286:F552-63.

15- Humphreys TL, Lee Ann Baldridge, Steven D. Billings, James J. Campbell, Stanley M. Spinola Trafficking Pathways and Characterization of CD4 and CD8 Cells Recruited to the Skin of Humans Experimentally Infected with Haemophilus ducreyi Infect Immun. 2005 Jul; 73(7): 3896-3902.

16- Prozialeck WS, Vaidya VS, Liu J, Waalkes MP, Edwards JR, Lamar PC, Bernard AM, Dumont X, Bonventre JV. Kidney injury molecule-1 is an early biomarker of cadmium nephrotoxicity Kidney Int. 2007 Oct; 72(8): 985993.

17- Zhou Y, Vaidya SV, Brown RP, Zhang J, Barry A. Rosenzweig, Karol L. Thompson KL, Miller TJ, Bonventre JV, Goerin PL. Comparison of Kidney Injury Molecule-1 and Other Nephrotoxicity Biomarkers in Urine and Kidney Following Acute Exposure to Gentamicin, Mercury, and Chromium. Toxicol Sci. 2008 Jan; 101(1): 159-170.

18-Han WK, Bailly V, Abichandani R, Thadhani R, Bonventre JV. Kidney Injury Molecule-1 (KIM-1): a novel biomarker for human renal proximal tubule injury. Kidney Int. 2002;62:237-44.

19- Vaidya VS, Ozer JS, Frank D, Fitz B. Collings FB, Ramirez V, Troth S, Muniappa N, Thudium D, Gerhold D, Holder DJ, Bobadilla NA, Marrer 
ISSN (Print):1992-92 18, ISSN (Online):1992-92 18

\section{DOI: https://doi.org/10.32792/utq/utjmed/18/2/1/01}

E, Perentes E, Cordier A, Vonderscher J, Maurer G, Goering PL, Sistare FD, Bonventre JV. Kidney Injury Molecule-1 Outperforms Traditional Biomarkers of Kidney Injury in Multi-site Preclinical Biomarker Qualification Studies Nat Biotechnol. 2010 May; 28(5): 478-485.

20-Vaidya VS ${ }^{1}$, Waikar SS, Ferguson MA, Collings FB, Sunderland K, Gioules C, Bradwin G, Matsouaka R, Betensky RA, Curhan GC, Bonventre JV. Urinary biomarkers for sensitive and specific detection of acute kidney injury in humans. Clin Transl Sci. 2008;1(3):200-8.

21-Ghayur T, Banerjee S, Hugunin M, Butler D, Herzog L, Carter A, Quintal L, Sekut L, Talanian R, Paskind M, Wong W, Kamen R, Tracey D, Allen H. Caspase-1 processes IFN-gamma-inducing factor and regulates LPS-induced IFN-gamma production Nature. 1997 Apr 10;386(6625):619-23.

22-Gu Y, Kuida K, Tsutsui H, Ku G, Hsiao K, Fleming MA, Hayashi N, Higashino K, Okamura H, Nakanishi K, Kurimoto M, Tanimoto T, Flavell RA, Sato V, Harding MW, Livingston DJ, Su MS. Activation of interferon-gamma inducing factor mediated by interleukin-1beta converting enzyme. Science. 1997 Jan 10;275(5297):206-9.

23-Gracie JA, Robertson SE, McInnes IB . Interleukin-18. J Leukoc Biol 2003;73 : $213-224$.

24- Parikh CR, Jani A, Melnikov VY, et al. Urinary interleukin-18 is a marker of human acute tubular necrosis. Am J Kidney Dis.2004, 43, 405-414

25- Parikh CR, Abraham E, Ancukiewicz M, et al. Urine IL-18 is an early diagnostic marker for acute kidney injury and predicts mortality in the ICU. J Am Soc Nephrol.2005, 16, 3046-3052.

26- Faubel $\mathbf{S}^{\mathbf{1}}$, Lewis EC, Reznikov L, Ljubanovic D, Hoke TS, Somerset H, Oh DJ, Lu L, Klein CL, Dinarello CA, Edelstein CL. Cisplatin-induced acute renal failure is associated with an increase in the cytokines interleukin (IL)-1beta, IL-18, IL-6, and neutrophil infiltration in the kidney. J Pharmacol Exp Ther. 2007 ;322(1):8-15

27-Fisher JW et al. Erythropoietin production by interstitial cells of hypoxic monkey kidneys. Br J Haemato. 1996, 95: 27-32

28- Warnecke $\mathbf{C}$ et al. Differentiating the functional role of hypoxia-inducible factor (HIF)-1 alpha and HIF-2alpha (EPAS-1) by the use of RNA interference: erythropoietin is a HIF-2alpha target gene in Hep3B and Kelly cells. FASEB J. 2004, 18: 1462-1464.

29-Scortegagna M, Ding K,Zhang Q, Oktay Y, Bennett MJ, Bennett M, Shelton JM, Richardson JA, Moe O, Garcia A. HIF-2alpha regulates murine hematopoietic development in an erythropoietin-dependent manner. Blood. 2005, 105:3133-3140.

30- Fisher JW. Erythropoietin: physiology and pharmacology update. ExpBioi Med (Maywood). 2003, 228: 1-14.

31- Anagnostou A et al. Erythropoietin receptor mRNA expression in human endothelial cells. ProcNatlAcadSci USA. 1994, 91: 3974-3978. 
ISSN (Print):1992-92 18, ISSN (Online):1992-92 18

\section{DOI: https://doi.org/10.32792/utq/utjmed/18/2/1/01}

32- Chong zz. et al. Hematopoietic factor erythropoietin fosters neuroprotection through novel signal transduction cascades. J Cereb Blood Flow Metab.2002, 22: $503-514$

33- Johnson DW, Pat B, Vesey DA, Guan Z, Endre Z, Gobe GC. Delayed administration of dar.bepoetin or erythropoietin protects against ischemic acute renal injury and failure. Kidney Int. 2006;69(10):1806-1813.

34- Westenfelder C. Unexpected renal actions of erythropoietin. ExpNephrol. 2002;10(5-6):294-298.

35- Jie KE et al. rythropoietin and the cardiorenal syndrome: cellular mechanisms on the cardiorenal connectors. Am J Physiol Renal Physio. 2006, 291: F932-F944

36- Beleslin-Cokic BB et al. (2004) Erythropoietin and hypoxia stimulate erythropoietin receptor and nitric oxide production by endothelial cells. Blood 104: 2073-2080

37-Salahudeen AK, Haider N, Jenkins J, et al. Antiapoptotic properties of erythropoiesis-stimulating proteins in models of cisplatin-induced acute kidney injury. Am J Physiol Renal Physiol. 2008;294(6):F1354-F1365

38- Ma R, Xiong N, Huang C, et al. Erythropoietin protects PC12 cells from beta-amyloid(25-35)-induced apoptosis via PI3K/ Akt signaling pathway. Neuropharmacology. 2009;56(6-7): 1027-1034.

39- Garg K, Yadav HN, Singh M, Sharma PL. Mechanism of cardioprotective effect of erythropoietin-induced preconditioning in rat heart. Indian $\mathbf{J}$ Pharmacol. 2010;42(4):219-223.

40- Mao W, Iwai C, Liu J, Sheu SS, Fu M, Liang CS. Darbepoetinalfa exerts a cardioprotective effect in autoimmune cardiomyopathy via reduction of ER stress and activation of the PI3K/Akt and STAT3 pathways. J Mol Cell Cardiol. 2008; 45(2):250-260.

41- Beuge JA, Aust SD. Microsomal lipid peroxidation. Meth Enzymol 1978; 52: 302-311.

42- McWhinnie DL, Thompson JF, Taylor HM, Chapman JR, Bolton EM, Carter NP, et al. Morphometric analysis of cellular infiltration assessed by monoclonal antibody labeling in sequential human renal allograft biopsies. Transplantation 1986;42: 352-358.

43-Striz I, Krasna E, Honsova E, Lacha J, Petrickova K, Jaresova M, Lodererova A, Bohmova R, Valhova S, Slavcev A, Vitko S. Interleukin 18 (IL-18) upregulation in acute rejection of kidney allograft. Immunol Lett. 2005 Jun 15;99(1):30-5.

44- Pabla N, Dong Z. Cisplatin nephrotoxicity: mechanisms and renoprotective strategies, Kidney Int. 2008, 73, 994e1007.

45- Hung YC, Huang GS, Lin LW, Hong MY, Se PS. Theasinensis melanin prevents cisplatin-induced nephrotoxicity in mice. Food Chem. Toxicol. 2007, $45,1123-1130$. 
ISSN (Print):1992-92 18, ISSN (Online):1992-92 18

\section{DOI: https://doi.org/10.32792/utq/utjmed/18/2/1/01}

46-Shimeda Y, Hirotani Y, Akimoto Y, Shindou K, Ijiri Y, Nishihori T, Tanaka $\mathbf{K}$ Protective effects of capsaicin against cisplatin-induced nephrotoxicity in rats Biol. Pharm. Bull. 2005, 28(9) 1635-1638.

47- Palipoch S, Punsawad C. Biochemical and histological study of rat liver and kidney injury induced by Cisplatin. J Toxicol Pathol. 2013 Sep;26(3):293-9.

48- El-Beshbishy HA, Bahashwan SA, Aly HA, Fakher HA. Abrogation of cisplatin-induced nephrotoxicity in mice by alpha lipoic acid through ameliorating oxidative stress and enhancing gene expression of antioxidant enzymes. Eur J Pharmacol. 2011; 668: 278- 284

49- Rashed LA, Hashem RM, Soliman HM. Oxytocin inhibits NADPH oxidase and P38 MAPK in cisplatin-induced nephrotoxicity. Biomed Pharmacother 2011; 65: 474-480

50- Deyang Kong, Zhuo L, ChangluGao, Shi S, Wang N, Huang Z, Li W, LirongHao. Erythropoietin protects against cisplatin-induced nephrotoxicity by attenuating endoplasmic reticulum stress-induced apoptosis. JNEPHROL 2013; 26(01): 219- 227.

51- Kharbanda S, Ren R, Pandey $\mathbf{P}$, et al. Activation of the c- Abl tyrosine kinase in the stress response to DNA-damaging agents. Nature. 1995;376(6543):785-788

52-Bagnis C, Beaufils H, Jacquiaud $\mathbf{C}$ et al. Erythropoietin enhances recovery after cisplatin-induced acute renal failure in the rat. Nephrol Dial Transplant 2001; 16: 932-938

53-Liu H, Baliga R. Endoplasmic reticulum stress-associated caspase 12 mediates cisplatin-induced LLC-PK1 cell apoptosis. J Am SocNephrol. 2005;16(7):1985-1992

54- Mehmeti I, Gurgul-Convey E, Lenzen S, Lortz S. Induction of the intrinsic apoptosis pathway in insulin-secreting cells is dependent on oxidative damage of mitochondria but independent of caspase-12 activation. BiochimBiophysActa. 2011;1813(10):1827-1835.

55- Breckenridge DG, Stojanovic M, Marcellus RC, Shore GC. Caspase cleavage product of BAP31 induces mitochondrial fission through endoplasmic reticulum calcium signals, enhancing cytochrome c release to the cytosol. J Cell Biol. 2003;160(7):1115-11273

56-Benjamin B, Ebert L, Bunn HF. Regulation of erythropoietin gene. Blood. 1999;94:1864-1877.

57-Siren AL, Ehrenreich H. Erythropoietin - a novel concept for neuroprotection. Eur Arch Psychiatry Clin Neurosci. 2001;251:179-184.

58- Calo LA, Bertipaglia L, Pagnin E. Antioxidants, carnitine and erythropoietin. G Ital Nefrol. 2006;34:547-550.

59-Ates E, Yalcin AU, Yılmaz S, Koken T, Tokyol C. Protective effect of erythropoietin on renal ischemia and reperfusion injury. ANZ J Surg. 2005;75:1100-1115. 
Web Site: $\underline{\text { https://jmed.utq.edu.iq }}$

Email:utjmed@utq.edu.iq

ISSN (Print):1992-92 18, ISSN (Online):1992-92 18

DOI: https://doi.org/10.32792/utq/utjmed/18/2/1/01

60-Sakanaka M, Wen TC, Matsuda S, Masuda S, Morishita E, Nagao M, et al. In vivo evidence that erythropoietin protects neurons from ischemic damage. Proc Natl Acad Sci USA. 1998;95:4635-40.

61- Bahlmann FH et al. Erythropoietin regulates endothelial progenitor cells. Blood. 2004, 103. 921-926.

الارثرويويتين يحسن الارتفاع المبكر في مستويات دلائل الاصابة الكلوية في الفئران المعالجة بالسيسبلانين

$$
\text { ا.م.د اياد علي حسين }
$$

جامعة الكوفة/كلية الصيدلة/فرع الصيدلة السريرية و العلاجيات

الخلفبة: العلاج الكيميائي سيسبلاتين يمكن أن يسبب إصابة الكلى الحادة (أكي) في حوالي •ب٪ من المرضى و الذي يشكل مشكلة كبيرة تحد من

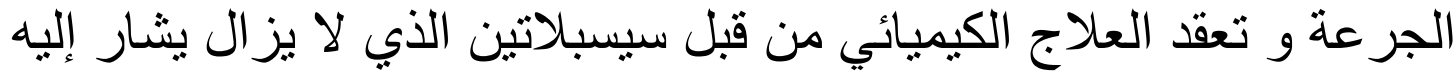

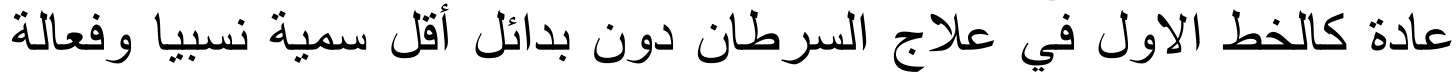

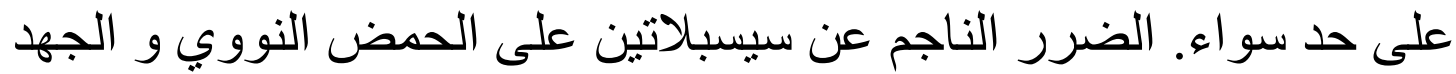

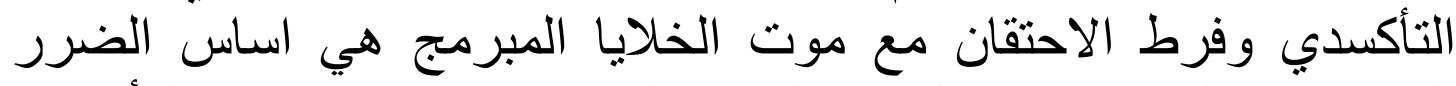

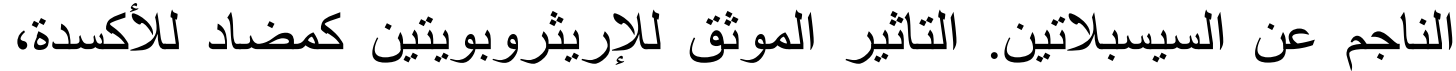

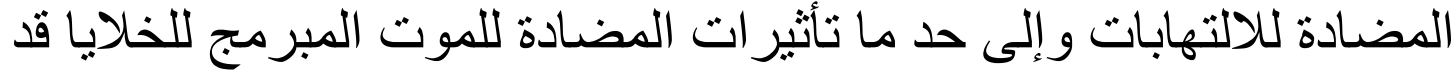

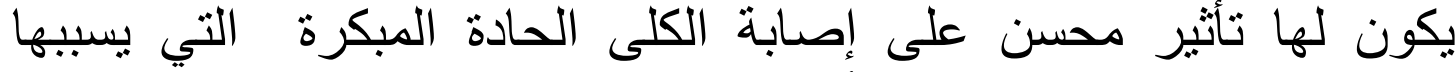

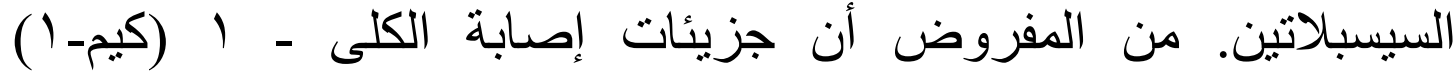

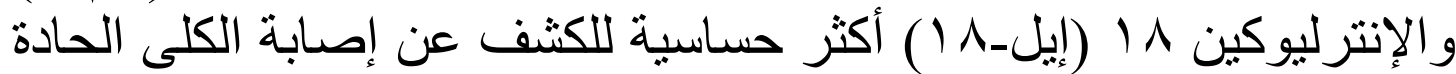

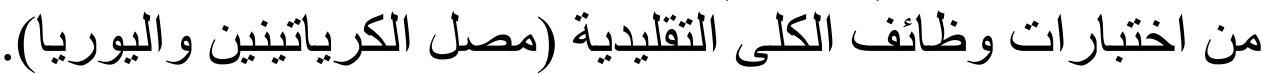
الكدف: تقييم تأثثر إريثروبويتين على الارتفاع الحاد المبكرفي معلمات

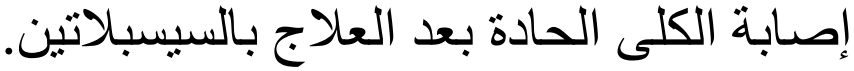

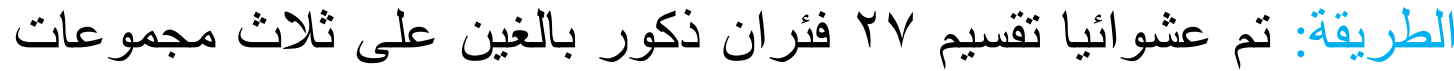

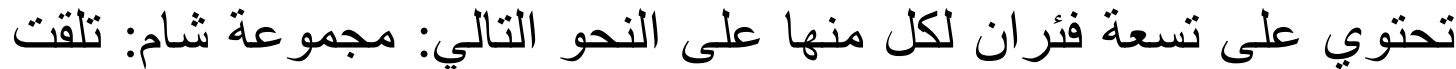

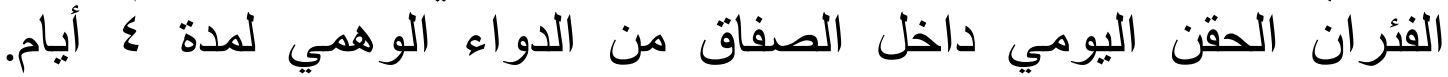

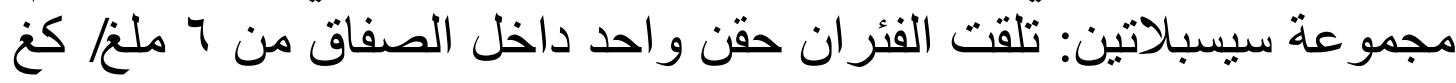


ISSN (Print):1992-92 18, ISSN (Online):1992-92 18

DOI: https://doi.org/10.32792/utq/utjmed/18/2/1/01

سبسبلاتين. مجمو عة السبسبلاتين + إربثروبويتين: تلقت الفئران حقن و احد داخل الصفاق من 7 ملغ/ كغ سبسبلاتين والحقن اليومي داخل الصفاق من الصني

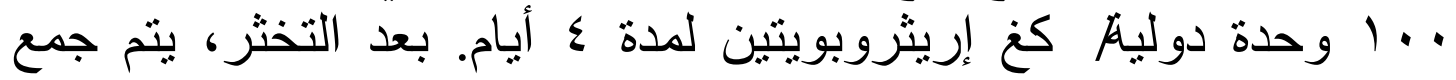
عينات الدم لقباس الكرياتينين في الدم، تتم معالجة الكلى لقياس الكلوي

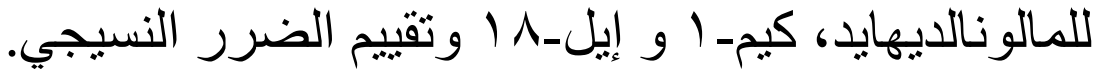

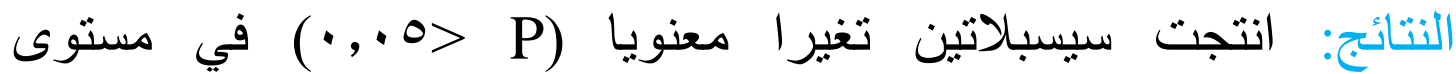

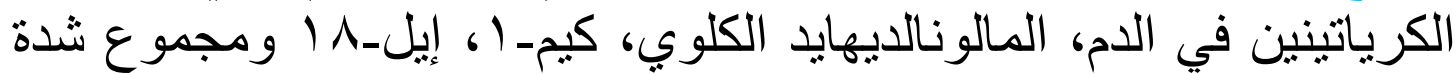
الضرر النسيجي المقارنة مع نلك الموجودة في مجمو عات أخرى. في

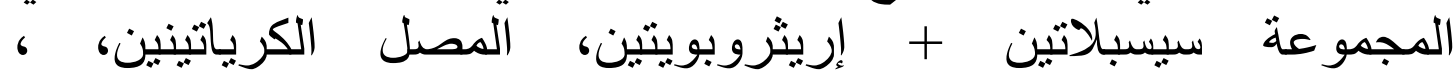

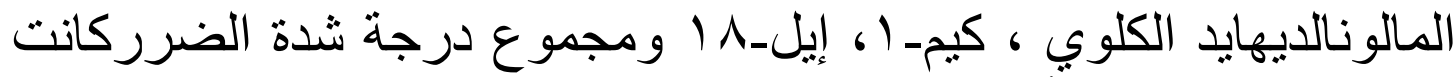

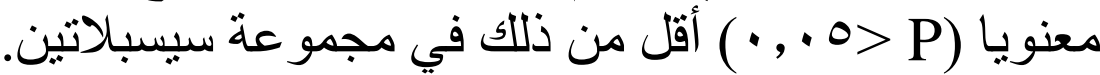
الخلاصنة: الإربثروبويتين حسن في وقت مبكر إصابة الكلى الحادة (أكي) التي بسببها السبسبلاتين الذي بتضح من خلال تحسين معلمات الإصـابة في و قت مبكر، التي تؤدي إلى ادخال الإريثروبويتين في وقت مبكر كاجرراء وقائي مبكر للحماية من إصنابة الكلى الحادة. 